\title{
Factors Affecting Mobile Banking Loyalty in Thailand
}

\author{
Phaninee Naruetharadhol ${ }^{1,2}$, Roland Koller ${ }^{1}$, Teerapong Nuanmanee ${ }^{1}$, Tanaton \\ Nimsrichan $^{1}$, Nathatenee Gebsombut ${ }^{1,2^{*}}$ \\ ${ }^{1}$ Business Adminitration Division, Global Business Program, International College, \\ Khon Kaen University, Khon Kaen, Thailand, 40002 \\ ${ }^{2}$ Global Entrepreneurship Development Center, Khon Kaen University, Khon Kaen, \\ Thailand, 40002
}

\begin{abstract}
An extensive inquisition on service quality has been a significant subject matter for centuries and has now developed in a manner of self-service technology (SSTs). SSTs service quality has a complex influence on the behaviour of customers in terms of interaction with banking organisations that involve activities of M-banking to establish and develop more significant customer satisfaction, loyalty, and service results. This study would like to examine technological based services impact based on SSTs service quality, goal framing theory, and customer loyalty in the M-banking service of a developing country. 698 M-banking's users have been collected through the online survey. Structural Equation Modelling was applied, and the results indicate positive and significant relationships among proposed indicators, including SSTs service quality, goal framing theory, and customer loyalty. The findings can help the banking industry to improve and provide necessary insights for the Banking industry, especially in the developing country like Thailand.
\end{abstract}

Keywords. Self Service Technologies, service quality, m,-banking, goal framing theory, customerloyalty.

\section{Introduction}

Internet technologies are growing and developing along with an abundance of smartphone and mobile applications, which interfered with a variety type of organisations and institutions to gain the advantage and profit of the following circumstances. E-Commerce illustrates the influence of Internet technologies in the world society's stage, which are requiring more significant products and services to respond to the massive demand of consumers. Mobile banking (M-banking) is one of the solutions that would facilitate and satisfy the needs of consumers in this industry. M-Banking is giving the idea of operating financial transactions anywhere and at any time, which is the strength factor why people started to value and prioritise using $\mathrm{M}$ Banking.

However, a minority of research has focused over factors of M-banking users' loyalty; as a result, no specific element would identify the customer loyalty in the new business model. Therefore, an essential strength of this study is to identify factors of

\footnotetext{
${ }^{*}{ }_{1}$ Corresponding Author: Nathatenee Gebsombut, International College, Khon Kaen University, Khon Kaen, Thailand, Email: phnathge@kku.ac.th
} 
M-banking users' loyalty. A primary key of this study is that its sample consisted of several executive research of intention in answering the customer loyalty on the impact of self-service technologies (SSTs) service quality on customer loyalty and behavioural intention [1]. Customer perspective of adoption and continuity intention are breaking M-banking barriers [2].

The purpose of this study is to identify and develop factors affecting M-banking users' loyalty by enhancing understanding of M-banking contribute to this research. This study would like to 1) identify factors impacting customer loyalty in M-banking users, 2) analyse impacts of critical factors on user's loyalty and satisfaction level in using M-banking, and 3) provide recommendations to banks strategic level management in terms of maintaining and increasing the level of loyalty by using Mbanking. This article contents include introduction, literature review, methodology, results, and conclusion parts, respectively.

\section{Literature Review}

\subsection{Mobile banking (M-banking)}

M-banking is the alternative way for users to have the ability to access their banking information and perform tasks on the application. Unlike traditional banking [3], Mbanking provides the ability for the user to perform banking transactions irrespective of place and time as the only requirement is the mobile network or wireless network access [4]. The M-banking application provides both users and bank with 24-hour basis operation. It gives the user easy access to the bank account through a mobile device and their ability to control their money transitions over the application platform [4]. Mbanking application is the alternative ways for many developed and developing countries to access bank, and it had significant effects on the market [5].

\subsection{SST service quality}

Term of service quality implies a formulation that united the process of service outcome [6] and service delivery [7]. The following terms of service quality have indicated relating dimensions of service quality, and its criterion of each aspect operated effectively, which was generating outstanding results in the past [8]. Researches in the topic of service quality have been reviewed as for considering and examining related model [9]. Conceptualised service quality as five dimensions can be called SERVQUAL to refer to the face-to-face environment of the service process. Service quality has consisted of the three-dimensional quality model introduced by Gronroos [10] including technical quality, functional quality, and corporate image. To give customers a more exceptional experience, to reach customer loyalty and retention, to minimise the cost from employees, and apply advanced technology into the business, an organisation is offering SSTs service quality [11]. SSTs service quality is technological dimensions that have the ability of interface which lets consumer get what they desire, such as services free from the involvement of the service persons [12].

Most of the significant studies field associated with technology found out that SSTs and call-centre services are empowered to obtain more consumers that involved services activity [13]. In consumer's perspective is concerned in term of service quality uses by the different to specific ideal on nature of self-service employed [14]. SSTs can 
increase and supplementing better services for the customer that can finish the transaction faster, anywhere, and anytime [15]. With more progressive of SSTs are speculated to reduce inessential delays in services, manage cost-effectively and consequently increase the level of customer's satisfaction that satisfy all the parties [16]

\subsection{Goal Framing Theory}

An individual has their way of understanding in each given information, which advised by sociology and psychology. The purpose of goal framing theory is aiming to instruct the literature of education to illustrate individual characteristics and differences in student learning. Goal-framing theory (GFT) by Lindenberg and Steg [17] recognises whether these objectives are selected autonomously or by their setting, that actors frequently pursue several different goals at the same moment. The GFT believes that actors are limited in their perception and understanding of their context. Eventually, GFT assumes that actors expect it to assess the alternatives accessible before they perform and to sort alternative solutions based on their performance capability [18]. GFT is not a practical strategy. It claims to include, for example, personal consent, the objectives of stakeholders are multifaceted and go beyond own welfare and utilities [19]. Besides, attitudes and hence attitudes are primarily affected by one's primary purpose, which may be non-utilitarian at the risk of other secondary objectives, which may be useful.

As a consequence, GFT can compensate for goal-oriented activities that may damage one's well-being [20]. Lindenberg [21] stated that as the goal are activated, they influence people's feeling in a way that improves or preserve the way one feels in a different situation. It can be in positive and negative emotions such as happiness, comfort, joy, guilt, anger, shame, and discomfort [22]. The individual with gain goal frame is generally is highly sensitive to their resources to maximise their benefits and securing their resources rather than caring about the negative external impact [22]. The normative goal frame acts as a sub-goal in determining how individuals think and work in the social group norm and long-term issues and control of passion. Each action of an individual in the normative goal frame would affect other people's possibilities.

\subsection{Self Service Technologies service quality correlates to customer loyalty}

Relationship between SSTs service quality and loyalty refers to service that customers spread and share the received experiences that became a possibility of returning for excellent service or by the term of word of mouth. Moreover, loyalty service means to improve on increasing purchases from customers and promotion by the company's offering [23]. However, customer loyalty has other definition which focuses on the mind-set of the consumer that is individually pleasing and committing the company's product and service which turn into customer loyalty and endorsement to the firm [24]. The most necessary component is service quality that has been proving by many reviews [25].

Likewise, experts expect that the company's overall value created by value, loyalty web and service quality which can increase the level of customer loyalty [26]. According to the online market, factors that pushing to achieve customer loyalty are product's value and customer satisfaction which mainly impact to customer loyalty in service quality [27]. Standard service quality dimensions with a positive influence can change on customer loyalty and happiness in the field of technology-based banking 
[28]. Consequently, brand equity becomes to be one of the most impactful service qualities in terms of customer loyalty [29].

When consumer appears to have positive senses to service experience and continuing good desire to return as a loyalty customer, one of the most influential factors considered to be the confines of satisfaction [30], satisfaction is a gratifying response of the customer. It was primarily an assessment of the attribute when a degree of delightfulness occurred from the consumption experience provided by the service or product [31]. Nevertheless, since satisfaction is corresponding, employing performance related to service or product has reached the expectation. At the same time, dissatisfaction occurs at the situation when the performance persists to be under the prospects [32]. Inquiry on the relationships among customer satisfaction and electronics service quality has also found a positive impact [33]. For retailer scenarios in airports, SSTs have a significantly positive effect on the joy of travellers [34].

Based on the study, figure 1 shows the following hypotheses.

H1: SSTs service quality is a second-order construct reflected by the first order consists of function, enjoyment, security, assurance, design, convenience, and customisation.

H2: Goal frame is a second-order construct reflected by the first order consists of a hedonic goal, gain goal, and normative goal.

H3: SSTs service quality has a direct positive impact on Goal frame.

H4: Goal frame has a direct positive impact on customer loyalty.

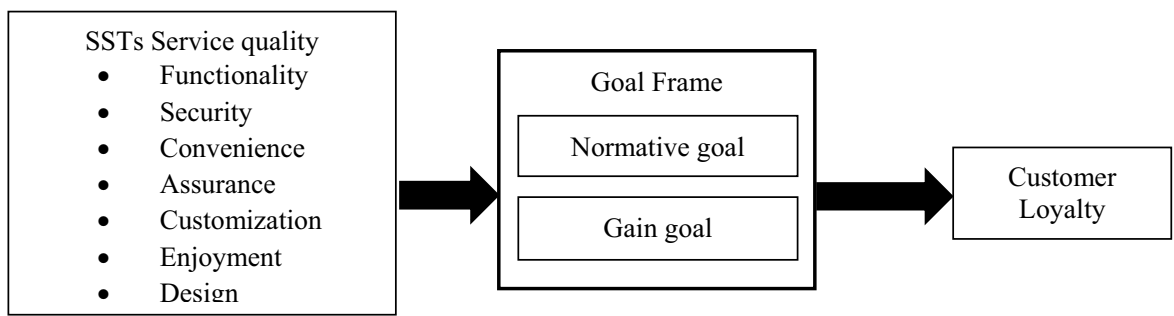

Figure 1: Hypothesised model.

\section{Methodology}

This study attempts to identify the core loyalty of customers using the application. This study filtered the measures used from the present literature and studied their validity, reliability, and modifications necessary adjustment with their invaluable information and feedback. This study used a seven-point-Likert scale from (1) strongly disagree to (7) strongly agree to evaluate the results. Before initiating a formal survey, pilot test measures were carried out on a sample of 30 randomly chosen persons, which generated fortified results. The research used the technique from Hair [35] to identify the sample size by variable multiple by ten responses, which most acceptable to determine. The research had developed questionnaires by studying from previous theories, concepts, and related research. The purpose of creating the survey is to identify and verify the factors of user loyalty. The questionnaires were developed and sent for proofreading, the content coverage, sorting, and the characteristics of the question. Then the survey was redeveloped and adjusted. After collecting data, SPSS was used to identify validity and reliability. The pilot test indicates that the 
questionnaire was in an acceptable internal consistency and reliability as the Cronbach's alpha of the whole measurement scale is higher than 0.7.

\section{Data Analysis and Results}

The research collected 710 online survey questionnaires. Table 1 shows demographic information, and also shows the associated behaviour of services on $\mathrm{M}$ banking application. The respondents had marked " $7 \mathrm{~s}$ " throughout on the 7-point scales, indicating on the variety of responses. There were deemed unacceptable and suitably omitted [36]. After examining scripts for any missing values, leave with the 698 scripts available for further analysis. The missing values were less than $1 \%$ of the total amounts, and these were replaced using Expectation-Maximisation algorithms [37]. Also, the study examined a confirmatory factor analysis [38] to determine for any method bias and to estimate a single method factor. The mean of factors was between 5.372 and 5.837, and the standard deviation value range between 1.076 and 1.268. The highest mean, perceived value was functionality at 5.837 with standard deviation at 1.268 , and the lowest mean was at 5.372 of security and privacy, and the standard deviation value at 1.123 . All correlations were positive, and all pairs were significantly were positive.

Table 1. Demographic and behaviour of services on M-banking application.

\begin{tabular}{|c|c|c|c|}
\hline Characteristics & Category & Quantity & Per cent $(\%)$ \\
\hline \multirow{2}{*}{ Gender } & Male & 264 & 37.8 \\
\hline & Female & 434 & 62.2 \\
\hline \multirow{4}{*}{ Education } & Undergraduate & 97 & 13.9 \\
\hline & Bachelor's Degree & 42 & 6.0 \\
\hline & Master's Degree & 499 & 71.5 \\
\hline & Doctoral Degree & 60 & 8.6 \\
\hline \multirow{5}{*}{ Income level } & Below 10,000 & 307 & 44.0 \\
\hline & $10,001-20,000$ & 164 & 23.5 \\
\hline & $20,001-30,000$ & 99 & 14.2 \\
\hline & $30,001-40,000$ & 64 & 9.2 \\
\hline & $40,001-50,000$ & 64 & 9.2 \\
\hline \multirow{4}{*}{$\begin{array}{l}\text { M-banking application } \\
\text { Frequency (per month) }\end{array}$} & Below 3 & 21 & 3.0 \\
\hline & $3-6$ & 97 & 13.9 \\
\hline & $7-9$ & 115 & 16.5 \\
\hline & Over 10 & 465 & 66.6 \\
\hline
\end{tabular}

Table 2. General theoretical model-fit.

\begin{tabular}{|l|l|l|l|l|l|}
\hline Fit index & $\begin{array}{l}\text { Recommended } \\
\text { value }\end{array}$ & SST & Goal framing & $\begin{array}{l}\text { Second-order } \\
\text { CFA }\end{array}$ & $\begin{array}{l}\text { Hypothesised } \\
\text { model (SEM) }\end{array}$ \\
\hline Chi-square/df & $\leq 3.00$ & 2.765 & 1.523 & 2.170 & 2.236 \\
\hline GFI & $\geq 0.80$ & 0.959 & 0.988 & 0.933 & 0.931 \\
\hline AGFI & $\geq 0.80$ & 0.938 & 0.978 & 0.917 & 0.916 \\
\hline CFI & $\geq 0.90$ & 0.983 & 0.997 & 0.976 & 0.975 \\
\hline RMSEA & $\leq 0.08$ & 0.050 & 0.027 & 0.041 & 0.042 \\
\hline
\end{tabular}

AMOS 26 was applied for data analysis. Model fit results are shown in Table 2. This research uses confirmatory factor analysis (CFA). The second-order CFA fit indexes are demonstrating a congenial fit to data (Normed $\mathrm{x} 2=2.170 ; \mathrm{CFI}=0.976$; GFI $=0.933$; AGFI $=0.917$; RMSEA $=0.041$ ) which introduce construct validity. Further tests of validity and reliability were also prosecuted. Supported by Hair et al. [37], every item in standardised loading was higher than 0.50 proposing sufficient 
convergent validity, additional support by the AVE scores also higher than 0.50 [39]. All constructs in composite reliability estimates and Cronbach's Alpha were over 0.80, representing acceptable reliability. Discriminant validity was advocated for most of the constructions as the primary constructs of AVE was larger than the successive standardised correlation coefficient with most of the other construction [39].

After inspecting the fit of the measurement model, this research inspected the second-order path loadings of SSTs service quality. This research noticed that selfservice technology significantly interpreted the first-order dimensions: function (standardized beta coefficient, $\beta=0.822, \mathrm{p}<0.001)$, enjoyment $(\beta=0.869, \mathrm{p}<0.001)$, security, $(\beta=0.894, \mathrm{p}<0.001)$, assurance $(\beta=0.926, \mathrm{p}<0.001)$, design $(\beta=0.929, \mathrm{p}$ $<0.001)$, convenience $(\beta=0.899, \mathrm{p}<0.001)$, and customization $(\beta=0.928, \mathrm{p}<0.001)$. The first-order CFA fit indexes of SSTs variables are demonstrating a congenial fit to data (Normed x $2=2.765 ; \mathrm{CFI}=0.983$; GFI $=0.959 ;$ AGFI $=0.938 ;$ RMSEA $=0.050$ ) which suggest construct validity and support H1. For hypothesis H2, this research noted the first-order dimensions of GFT as Gain goal $(\beta=0.993)$, and Normative goal $(\beta=0.931)$. The first-order CFA fit indexes of goal framing variables are demonstrating a congenial fit to data (Normed x $=1.523$; CFI $=0.997$; GFI $=0.988$; AGFI $=0.978$; RMSEA $=0.027$ ) which suggest construct validity. The result supports hypothesis $\mathrm{H} 2$.

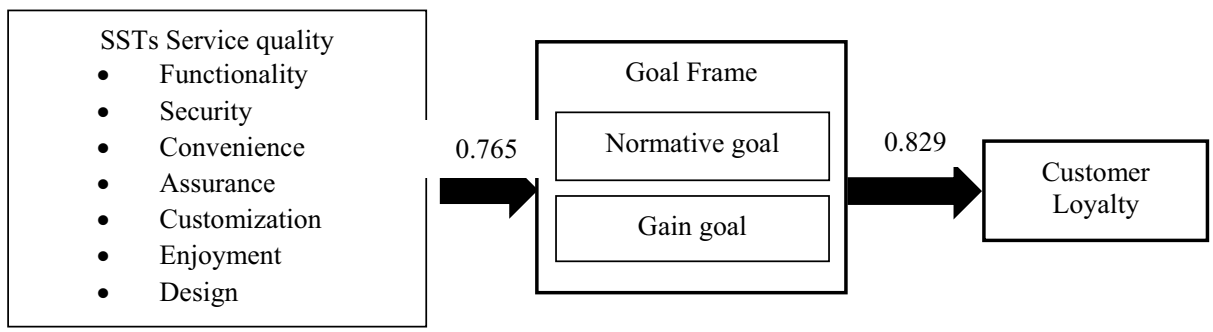

Figure 2: Hypothesised.

The hypothesized measurement model of this research yielded was at Normed $\mathrm{x} 2=$ 2.236; CFI $=0.975$; RMSEA $=0.042$; CFI $=0.975$; GFI $=0.931$; AGFI $=0.916$. Selfservice technology exerted a significant influence on values perceived in Goal framing theory $(\beta=0.765, \mathrm{CR}=17.459, \mathrm{p}<0.001)$. The result of the model reached path coefficients of 0.765 , supporting hypothesis H3. Moreover, completion of GFT exerts a significant impact on customer loyalty $(\beta=0.829, C R=20.761, p<0.001)$, the result of the model reached path coefficients of 0.829 . Therefore, hypothesis H4 is supported.

\section{Discussion and Conclusion}

This study applies the SSTQUAL scale [30] to measure the service quality of SSTs in the context of Thailand service sector. This study has shown that younger customers have more significant trends toward the utilising of SSTs. SSTs service quality has a positive and meaningful relationship with customer loyalty. The outcome tells that customer loyalty towards the SSTs will be greater, the more customers receive high service quality from SSTs they are utilising. The findings are in line with McKecnie et al. [28] that the impacts of generic service quality aspects in a technology-based banking framework and identified a positive effect of service quality aspects on 
customer loyalty. GFT mediates the association between SSTs service quality and customer loyalty to a certain degree. As well as the structural model, the SSTs service quality is positively and significantly affected the customer's perceived values through one of the goal frames in GFT. Finally, an affirmative act upon each goal frame from GFT is associated substantially with SSTs user's loyalty and intention of continuous use. The outcome of the study research provides a significant role in the practical and managerial implications of the banking industry that gives knowledge of consumer's perspective and expertise to understand the attitude through the model of SSTs service quality, GFT, and customer loyalty. Hence, banks should have prioritised, giving more efforts to understanding reaction and behaviour that can affect the satisfaction and dissatisfaction of involving M-banking customers. This study can help banking industry to improve quality of service to allow users be able to access to necessary information that solve the pain point of customers. They can do so by improving on consistent monitoring, management, and service delivery process towards the use of following provided models. This study has several limitations. First, the data that this study collected data only from M-banking users in Thailand. Due to this condition, the data of other provinces may have different outcomes and attitudes according to the theoretical methods system simultaneously. Finally, this study research has a limitation on data collection time.

\section{References}

[1] M. Shahid Iqbal, M. U1 Hassan, and U. Habibah, "Impact of self-service technology (SST) service quality on customer loyalty and behavioral intention: The mediating role of customer satisfaction," Cogent Bus. Manag., vol. 5, no. 1, pp. 1-23, 2018.

[2] A. W. Siyal, D. Ding, and S. Siyal, "M-banking barriers in Pakistan: a customer perspective of adoption and continuity intention," DATA Technol. Appl., vol. 53, no. 1, pp. 58-84, Feb. 2019.

[3] A. A. Shaikh and H. Karjaluoto, "Mobile banking adoption: A literature review," Telemat. Informatics, vol. 32, no. 1, pp. 129-142, 2015.

[4] M. N. O. Sadiku, M. Tembely, S. M. Musa, and O. D. Momoh, "Mobile Banking," Int. J. Adv. Res. Comput. Sci. Softw. Eng., vol. 7, no. 6, pp. 75-76, 2017.

[5] R. Safeena, H. Date, A. Kammani, and N. Hundewale, "Technology Adoption and Indian Consumers: Study on Mobile Banking," Int. J. Comput. Theory Eng., vol. 4, no. 6, pp. 1020-1024, 2012 .

[6] J. R. Lehtinen, "Two approaches to service quality dimensions," Serv. Ind. J., 1991.

[7] L. L. Berry, V. A. Zeithaml, and A. Parasuraman, "Quality counts in services, too," Bus. Horiz., 1985 .

[8] S. Jain and S. K. Gupta, "Analysis of modified surface force pore flow model with concentration polarisation and comparison with Spiegler-Kedem model in reverse osmosis systems," J. Memb. Sci., 2004.

[9] J. J. Cronin, M. K. Brady, and G. T. M. Hult, “Assessing the effects of quality, value, and customer satisfaction on consumer behavioral intentions in service environments," J. Retail., 2000.

[10] C. Grönroos, “A Service QGrönroos, C. (1984). A Service Quality Model and its Marketing Implications. European Journal of Marketing. doi:10.1108/EUM0000000004784uality Model and its Marketing Implications," European Journal of Marketing. 1984.

[11] C. H. Tsou et al., "Immersive VR Environment for Architectural Design Education," in SIGGRAPH Asia 2017 Posters, SA 2017, 2017.

[12] M. J. Bitner, S. W. Brown, and M. L. Meuter, "Technology infusion in service encounters," J. Acad. Mark. Sci., 2000.

[13] E. Considine and K. Cormican, "Self-service Technology Adoption: An Analysis of Customer to Technology Interactions," in Procedia Computer Science, 2016.

[14] G. M. Rose, M. L. Meuter, and J. M. Curran, "Online waiting: The role of download time and other important predictors on attitude toward e-retailers," Psychology and Marketing. 2005.

[15] S. E. Kimes and J. E. Collier, "How customers view self-service technologies," MIT Sloan 
Management Review. 2015.

[16] B. Weijters, D. Rangarajan, T. Falk, and N. Schillewaert, "Determinants and outcomes of customers' use of self-service technology in a retail setting," J. Serv. Res., 2007.

[17] S. Lindenberg and L. Steg, "Goal-framing theory and norm-guided environmental behavior," in Encouraging Sustainable Behavior: Psychology and the Environment, 2013.

[18] S. Lindenberg and L. Steg, "Normative, gain and hedonic goal frames guiding environmental behavior," J. Soc. Issues, 2007.

[19] L. Minkler, "The problem with utility: Toward a non-consequentialist/utility theory synthesis," Rev. Soc. Econ., 1999.

[20] J. C. Banfield, S. Shepherd, and A. C. Kay, "Consequences of system defense motivations for individuals' willingness to act sustainably,” Encourag. Sustain. Behav. Psychol. Environ., no. August 2015, pp. 111-124, 2013.

[21] S. Lindenberg, "Social Rationality versus Rational Egoism," in Handbook of Sociological Theory, 2006.

[22] J. Etienne, "Compliance theory: A goal framing approach,” Law Policy, 2011.

[23] J. Lee, J. Lee, and L. Feick, "The impact of switching costs on the customer satisfaction-loyalty link: Mobile phone service in France," J. Serv. Mark., 2001.

[24] Q. M. Pearson, "Treatment Techniques for Adult Female Survivors of Childhood Sexual Abuse," J. Couns. Dev., 1994.

[25] C. Makanyeza and L. Chikazhe, "Mediators of the relationship between service quality and customer loyalty: Evidence from the banking sector in Zimbabwe," Int. J. Bank Mark., 2017.

[26] A. Parasuraman and D. Grewal, "The impact of technology on the quality-value-loyalty chain: A research agenda," J. Acad. Mark. Sci., 2000.

[27] Z. Yang and R. T. Peterson, "Customer perceived value, satisfaction, and loyalty: The role of switching costs," Psychol. Mark., 2004.

[28] S. McKecnie, S. Ganguli, and S. K. Roy, "Generic technology-based service quality dimensions in banking: Impact on customer satisfaction and loyalty,” Int. J. Bank Mark., 2011.

[29] V. Venkatesh, J. Y. L. Thong, and X. Xu, "Consumer acceptance and use of information technology: Extending the unified theory of acceptance and use of technology," MIS Q. Manag. Inf. Syst., 2012.

[30] J. S. C. Lin and P. L. Hsieh, “Assessing the Self-service Technology Encounters: Development and Validation of SSTQUAL Scale,” J. Retail., 2011.

[31] C. Oliver, "Sustainable competitive advantage: Combining institutional and resource-based views," Strateg. Manag. J., 1997.

[32] J. E. Swan and L. J. Combs, "Product Performance and Consumer Satisfaction: A New Concept," J. Mark., 1976.

[33] K.-W. WU, "Customer Loyalty Explained by Electronic Recovery Service Quality: Implications of the Customer Relationship Re-Establishment for Consumer Electronics E-Tailers," Contemp. Manag. Res., 2011.

[34] V. Bogicevic, M. Bujisic, A. Bilgihan, W. Yang, and C. Cobanoglu, "The impact of travelerfocused airport technology on traveler satisfaction," Technol. Forecast. Soc. Change, 2017.

[35] J. Hair, W. Black, B. Babin, and R. Anderson, "Multivariate Data Analysis: A Global Perspective," in Multivariate Data Analysis: A Global Perspective, 2010.

[36] N. K. Malhotra, "Marketing research: An applied orientation (Vol. 834)." New Jersey: Pearson Education, 2010.

[37] J. F. Hair, W. C. Black, B. J. Babin, and R. E. Anderson, Multivariate data analysis, 7th ed. Englewood Cliffs, N.J.: Prentice Hall, 2009.

[38] P. M. Podsakoff, S. B. MacKenzie, J.-Y. Lee, and N. P. Podsakoff, "Common method biases in behavioral research: A critical review of the literature and recommended remedies.," J. Appl. Psychol., vol. 88, no. 5, p. 879, 2003.

[39] C. Fornell and D. F. Larcker, "Evaluating Structural Equation Models with Unobservable Variables and Measurement Error,” J. Mark. Res., vol. 18, no. 1, pp. 39-50, 1981. 